\title{
Mainstream Sell-Outs? How Collaboration with the Radical Right Changes Perceptions of Party Positions on Immigration
}

\author{
Ida B. Hjermitslev ${ }^{\star}$ \\ Department of Government, University of Vienna, Vienna, Austria \\ ${ }^{\star}$ Corresponding author. Email: ida.hjermitslev@univie.ac.at
}

(Received 3 February 2020; revised 24 September 2020; accepted 2 October 2020;

first published online 3 December 2020)

\begin{abstract}
European mainstream right parties are increasingly choosing to include radical right parties in coalition governments or other types of stable and committed cooperation. How does this cooperation affect voters' perceptions of party positions? This article examines whether coalition signals have a significant impact on voters' perceptions of the specific policy issues that were at stake in the bargaining process. More specifically, does the issue ownership of the radical right cause voters to perceive mainstream parties as radicalizing on immigration issues pertaining to asylum and multiculturalism? I compare the perceptions of Dutch parties before and after two coalition formations that (formally and informally) involved a radical right party: the coalition with the List Pim Fortuyn in 2002 and the support agreement with the Freedom Party in 2010. Furthermore, I examine the long-term effects of the Danish mainstream right government's reliance on the support of the radical right Danish People's Party in 2001-11.
\end{abstract}

Keywords: radical right; coalition formation; party positions; multiculturalism and immigration; external support parties; voter perceptions

At the very beginning of the millennium, William Downs (2001) suggested that mainstream parties might adopt a strategy of cooperating with radical right parties. He argued that in doing so, they risk being perceived by voters as 'sell-outs' who have compromised their liberal principles. Twenty years later we have witnessed radical right parties joining coalitions or supporting minority governments in several European countries. Hence, it seems that from the perspective of mainstream right parties, this risk is increasingly considered worth taking.

Studies show that voters use coalition heuristics to estimate the policy positions of parties, and as a result voters generally tend to perceive parties that govern together in a coalition as more ideologically similar than they would have otherwise (Adams et al. 2016; Fortunato and Adams 2015; Fortunato and Stevenson 2013a). This

(C) The Author(s), 2020. Published by Cambridge University Press on behalf of Government and Opposition Limited. This is an Open Access article, distributed under the terms of the Creative Commons Attribution licence (http://creative commons.org/licenses/by/4.0/), which permits unrestricted re-use, distribution, and reproduction in any medium, provided the original work is properly cited. 
disproportionately affects junior coalition members in general and niche party coalition members in particular, perhaps because voters do not trust these parties to have the same substantial impact on government policy. Large mainstream parties are partially insulated from the effects of coalition formation on voters' perceptions, while smaller parties are perceived as compromising 'sell-outs' (Fortunato and Adams 2015: 15-16). This could be one of the mechanisms creating differences in the electoral cost of governing (Hjermitslev 2020). While this might be true on the general left/right dimension, we do not know if it extends to specific policy issues.

In this article, I explore to what extent and on which issues public perceptions of party positions are affected by collaborations between the mainstream and radical right. Based on a theory of log-rolling and tangential preferences, I suggest that voters will project the positions of the mainstream right onto the radical right on the general left/right dimension and on economic issues. However, on the core issues of the radical right, specifically on immigration, voters will assume that the mainstream right has made significant concessions to the radical right and thus perceive them as more restrictive on these issues.

This article unites two different literatures and extends them in novel ways. First, it moves the literature on coalition heuristics from a sole focus on the abstract left/ right dimension, towards thinking more carefully about how the mechanism linking coalition formation and spatial perceptions works on more specific issues. Second, it contributes to the party competition literature, which has so far focused entirely on how mainstream parties respond strategically in order to compete with radical right parties. This literature tends to be about general and long-term trends caused by electoral competition rather than about inclusion of or coalition formation with the radical right. To my knowledge, no one has looked at perceptions following cooperation and whether mainstream parties incur a reputation for radicalizing when they join forces with the radical right. One of the main contributions of this article is to explore the possibility that mainstream parties will risk being perceived as 'selling out' on their liberal principles concerning immigration and multiculturalism in order to form coalitions with radical right parties.

\section{Moderation or accommodation?}

For a long time, research on radical right parties was mainly focused on explaining their electoral success (see e.g. van der Brug et al. 2005), while their impact on policymaking and party competition was under-studied (Abou-Chadi and Krause 2020; Han 2015; van Spanje 2010). In recent years, a number of studies have tried to fill this gap by exploring what the long-term effects of radical right success might be. There is a general expectation that radical right parties have become more mainstream, either because they have moderated to become respectable potential coalition members or because their mainstream competitors have adopted radical policy stances to diffuse the threat posed by the radical right (Wagner and Meyer 2017).

That radical right parties will moderate in order to cooperate with other parties is central to the inclusion-moderation thesis (Akkerman and Rooduijn 2015; van Spanje and van der Brug 2007). If a party is systematically excluded from any sort of cooperation on principle it will have no incentive to moderate its positions. Furthermore, party supporters might interpret the ostracism as a violation of their 
democratic rights and develop strong feelings of in-group solidarity and dissatisfaction with the political system. In contrast, radical right parties are likely to tone down their criticism of the establishment and become more amenable when they are themselves part of the government.

The results provide mixed support for this theory. Joost van Spanje and Wouter van der Brug (2007) found that perceived moderation by the radical right on the left/right scale is more likely when mainstream parties do not construct a cordon sanitaire. Inclusion means that the radical right are perceived as a legitimate part of the system. Tjitske Akkerman and Matthijs Rooduijn (2015) similarly asked how inclusion or exclusion affects the policy agendas of radical right parties but did not find a moderating effect. Contrary to the inclusion-moderation thesis, they found that the lack of a cordon sanitaire made parties even more radical in their manifesto positions towards immigration. Radical right parties might start to look more like mainstream parties in terms of their behaviour when they cooperate with other parties in the legislature or in government, but their policy positions on the core issues remain as extreme as before (Akkerman et al. 2016).

Furthermore, scholars have examined how cooperation affects the electoral fortunes of radical right parties. Tjitske Akkerman and Sarah De Lange (2012) examined the electoral success of six radical right parties after they joined government. They argued that voters attribute credit and blame according to issue ownership. Thus, the radical right are evaluated based on their ability to ensure more restrictive immigration and integration policy. Van Spanje (2011) argued that radical right parties suffer an extra cost of governing, because they are perceived as losing the purity of their anti-establishment messages: they can no longer claim that they want to kick the establishment out of office. In short, radical right parties might be perceived as more moderate and part of the establishment, but they still explicitly take extreme policy positions on their core issues and voters expect them to deliver.

There is less disagreement about how the mainstream parties have moved to the right, although scholars are discussing the exact mechanisms driving this. There appears to be a general long-term contagion effect such that mainstream parties adopt more anti-immigrant and monoculturalist positions as a reaction to the success of the radical right (Abou-Chadi 2016; Han 2015; van Spanje 2010), also known as an accommodating strategy (Meguid 2005). Independent of public opinion, which appears remarkably stable (Dennison and Geddes 2019), the entry of radical right parties into parliament caused mainstream parties to shift their positions on multiculturalism (Abou-Chadi and Krause 2020). Radical right parties are often described as 'challenger' or 'blackmail' parties (Downs 1957) who are changing the competitive space. Representation in parliament can be considered a critical point where the radical right becomes an electoral threat to which mainstream parties must react, because at this point they become established parties with access to more resources and media attention.

According to Markus Wagner and Thomas Meyer (2017), radical right success has motivated both mainstream left and mainstream right parties to move to the right on the secondary cultural dimension over time. This means that the average position of the mainstream left is as far right today as the average position of the radical right was in the 1980s. Akkerman (2015), on the other hand, found that there was virtually no effect for the mainstream left parties, and even for 
mainstream right parties, who were on a path towards more restrictive immigration policies independently, the impact of the radical right is easy to overestimate. She also warned against thinking in broad ideological terms such as the 'cultural dimension'. Instead mainstream parties are adopting a mixed strategy where they only adopt radical right positions on a few very specific issues within the broader immigration issue area while maintaining more permissive stances on others.

Prior literature on accommodation has focused entirely on how mainstream parties will approach radical right parties in order to compete with them. While there is an idea that radical right parties will be perceived as moderate when they cooperate with mainstream parties, to the best of my knowledge, no one has seriously examined whether mainstream parties will incur a reputation for radicalizing when they join forces with the radical right. The main contribution of this article is to explore the possibility that mainstream parties will risk being perceived as selling out on their liberal principles concerning immigration and multiculturalism so that they can form coalitions with radical right parties.

\section{The effects of coalition formation on voters' perceptions}

Several recent studies have argued that voters rely on coalition information when estimating the policy positions of parties in the governing coalition (Adams et al. 2016; Fortunato and Adams 2015; Fortunato and Stevenson 2013a; Spoon and Klüver 2017). Parties in government are perceived as closer to one another than they are to parties in the opposition, holding everything else constant. A party's status as a member of either the governing coalition or the opposition is a cheap and widely available source of information about its policy position (Fortunato and Stevenson 2013b).

Coalitions with less internal conflict of interest find it easier to form and govern together and are thus preferred by its members (Laver and Schofield 1998: 97-98). It follows that the coalitions that form will often be ideologically connected and that members will be adjacent to each other on the left/right spectrum. An important implication of this model is that the choice of coalition partner is an important signal about a party's policy positions (Fernandez-Vazquez 2014; Fortunato and Stevenson 2013a).

If the prime minister puts together the coalition and describes the overarching guidelines for its political programme, it seems natural that voters will use the prime minister's party's ideology as a focal point when thinking about the ideological position of the entire coalition on the general left/right spectrum. David Fortunato and Jim Adams (2015) have demonstrated that the change in perceptions of parties' left/right position was asymmetrical. Voters map the prime minister's left/right position onto junior coalition members, but not vice versa. Since radical right parties have few coalition alternatives, they have a weak bargaining position, and usually become the junior coalition member (Akkerman and De Lange 2012: 579-580). Consequently, voters will expect them to have difficulties realizing their policy goals on the left/right.

Hypothesis 1: Following cooperation between the mainstream and the radical right, voters will perceive radical right coalition members' positions on the general left/right dimension as closer to the positions of the mainstream right. 
However, there are alternative ways of negotiating. If one takes salience into account, one might find that coalition formation is not just a question of similarity in positions, but also about differences in emphasis. Parties have incentives to select coalition partners that neither inhibit policy goals nor pose a threat in the electoral competition. A coalition partner with similar policy positions will naturally appeal to the same voters, while a coalition partner with very different positions is hard to negotiate with. But if each party holds certain issues to be more salient than others, there is the potential for a type of formalized log-rolling.

According to the theories of issue ownership (Budge and Farlie 1983; Petrocik 1996), all parties have a policy profile with certain core issues that are particularly important to them. Much has been written in recent years about how these policy profiles influence electoral competition and how niche parties, especially, attempt to change the political agenda and increase the salience of the issues they own. However, very few scholars have paid attention to how issue profiles might constrain or facilitate coalition formation.

Gregory Luebbert (1986) argues that these issue priorities will be decisive in the bargaining in a governing coalition. Tangential preferences are compatible because coalition members address different unrelated issues. If one coalition partner emphasizes one issue, and the other(s) emphasizes another, it might be easier for them to agree on a shared policy platform. This type of relationship is preferable because it allows parties to preserve the distinctiveness of their platform and does not require them to give resources and influence to a competitor in the electoral market (Luebbert 1986: 64). Log-rolling is a strategy of delegation rather than accommodation and it can be an attractive option for both mainstream and radical right parties.

The model suggests that parties with complementary policy agendas - that is, tangential preferences - will focus on their own issues, while delegating control of other issues to their coalition partners. This delegation is most obvious when cabinet members obtain ministerial portfolios that correspond to the issues they emphasize (Bäck et al. 2011; Saijo 2020), but log-rolling is most likely a part of less formalized types of cooperation as well. For instance, mainstream right parties make concessions to radical right parties on immigration issues in exchange for leverage over economic policy (Akkerman and De Lange 2012: 579-580). By logrolling, radical right parties can minimize compromises on their core issues such as immigration and multiculturalism (Akkerman et al. 2016). Voters are well aware of this delegation of responsibility: they know that some parties have more leeway on certain issues, and this influences their perceptions of party positions.

Voters focus on the policy position of the coalition member in charge of the issue. They are mainly concerned with political outcomes and the policy consequences associated with supporting any member of the coalition - not with the policies that individual parties are advocating during the election campaign (Fortunato and Stevenson 2013a). Voters care less about whether coalition members are sincerely accommodating and approaching each other. They simply observe that the mainstream parties are facilitating radical right immigration policy and hence they will use the radical right position to place all coalition members on this issue. Similarly, they know that the radical right are lending votes to mainstream right economic policy and thus place all members closer to the mainstream right 
position. Furthermore, being in charge is associated with higher exposure to the party position. Because voters possess more knowledge about the positions of the governing party that attributes higher salience to an issue, it is natural for them to use this knowledge when placing other, more vague and diffuse, coalition members.

This leads to the following issue-specific hypotheses:

Hypothesis 2: Following cooperation between the mainstream and the radical right, voters will perceive mainstream right coalition members' positions on immigration as closer to the position of the radical right.

Hypothesis 3: Following cooperation between the mainstream and the radical right, voters will perceive radical right coalition members' positions on economic issues as closer to the positions of the mainstream right.

Hypothesis 2 runs directly counter to predictions made elsewhere. According to Fortunato and Adams (2015), niche parties, more so than other parties, depend on maintaining a distinct policy profile. They risk losing the purity of their message and being perceived as compromising when they join coalition governments. My theory suggests that this might be true on economic issues and on the general left/right dimension, but not on the issues they actually care about.

Most other researchers have focused exclusively on the left/right dimension, with the notable exception of Adams et al. (2016), who looked at party placement on a scale concerning European unification. They found that voters' perceptions are also affected by coalition formation when it comes to EU policy, but it is unclear if it is more or less than on the left/right dimension. Furthermore, it is quite hard to extrapolate to any other issue since European unification is an extremely multifaceted high-level issue that spills over into both economic and immigration issues.

\section{Case selection: the radical right in government}

Testing these three hypotheses requires substantial variation in the salience profile of the coalition members. This is complicated because governing parties tend to be mainstream parties that emphasize traditional economic issues. There are relatively few instances of radical right parties in government. On top of that, I can only look at cases where survey data with consistent measurement of party placement on issues over time are available. This narrows the field down to the Netherlands and Denmark.

There is only one brief instance where a radical right party became an official coalition member (strong treatment), but two instances where a coalition relied on the external legislative support of the radical right (weak treatment). In line with Akkerman and De Lange (2012), I argue that the collaboration between the Danish mainstream right and the Danish People's Party (DF) from 2001 onwards, as well as that between the Dutch mainstream right and the Freedom Party (PVV), represents a type of coalition-like government. Both parties were part of a more or less permanent coalition that ensures acceptance of all or almost all government proposals (De Swaan 1973: 85). 
Are these parties radical? Perhaps not in the sense originally suggested by William Downs (2001). The radical right parties that eventually make it into government are not directly anti-democratic, but rather extreme outliers in terms of their positions towards immigration. This attention to a particular issue is exactly what makes them suitable for testing the hypotheses outlined above. Antidemocratic tendencies could not have served as a tangential preference around which parties could build a coalition.

Do these parties have a niche salience profile? It has been argued that radical right parties have increased their emphasis on economic issues and have attempted to frame them in ways that support an ideology of welfare chauvinism (Wagner and Meyer 2017). Welfare chauvinism is the belief that immigrants make excessive use of the welfare state and that access should be restricted to the 'deserving' natives. This links left-wing economic attitudes with right-wing views on immigration. According to Gijs Schumacher and Kees van Kersbergen (2016), this approach was pioneered by the DF and has been adopted by other parties such as the PVV. However, according to the analysis of Wagner and Meyer (2017), there was no evidence of salience moderation by the Danish radical right parties, and only limited moderation in the Netherlands.

\section{Strong treatment: the radical right as a coalition member}

Prior to the 2002 election, the Dutch government was run by the so-called 'purple coalition' consisting of the social democratic Labour Party (PvdA) and the liberal People's Party for Freedom and Democracy (VVD) and Democrats 66 (D66). This broad centrist government agreed on most of the economic policy as well as the key ethical issues: same-sex marriage, same-sex adoption and euthanasia. The main opposition party, the Christian Democratic Appeal (CDA), was forced to acknowledge these positions if it was to participate in a coalition in the near future (Pellikaan et al. 2003). As a result, many issues were not particularly salient in the 2002 election. Instead, the newly emerged List Pim Fortuyn (LPF) was able to set the political agenda. The news in the early spring of 2002 was centred around Pim Fortuyn's viewpoints on asylum-seekers, immigration and Islam as well as the mainstream parties' attempt to dismiss him as unacceptable (Van Hoof et al. 2003).

In many ways, the LPF is not the ideal-typical radical right party (Mudde 2007): Pim Fortuyn himself rejected the label and was an ardent defender of gay rights, gender equality and other liberal policies (Brubaker 2017). Likewise, the party was not uniformly against immigrants: for example, the LPF suggested a general pardon for illegal immigrants (Van Hoof et al. 2003). Nevertheless, in terms of its issue profile, which is the object of interest in this particular context, the LPF is undeniably a niche party with strong viewpoints on immigration and multiculturalism.

Aside from his anti-immigration policies, Fortuyn successfully mobilized voters who were dissatisfied with politics and thought that the mainstream parties had become too similar (Silva 2018). The rapid rise of the LPF caused a regular realignment of Dutch politics in which mainstream parties quickly adopted new tough stances on immigration (De Lange 2012: 910-911). The liberal VVD was already 
on a path towards a more restrictive immigration policy, but the rise of the LPF accelerated this process considerably (Akkerman 2015).

Despite the assassination of Pim Fortuyn himself, the LPF entered parliament with 26 seats, more than any new party ever before, and managed to become the second-largest party. As a result it was invited into government negotiations and eventually formed a coalition government with the CDA and VVD under the leadership of Jan Peter Balkenende (Van Holsteyn et al. 2003). That it only took 68 days to negotiate the coalition agreement could suggest that the three parties were already quite close to each other (De Lange 2012). The LPF supplied four ministers to the cabinet and became in charge of health, transport, economic affairs and integration and asylum - the latter without portfolio.

However, the LPF quickly suffered from the loss of its charismatic leader and lack of party organization. The LPF ministers were unable to settle their differences and obstructed the workings of the entire coalition government (Bos and van der Brug 2010; van Holsteyn et al. 2003). Meanwhile the support for the LPF in public opinion polls quickly dropped. By October it was only equivalent to four seats in parliament and the coalition government split. The cabinet including the LPF was not successful in implementing any new legislation on immigration (Akkerman and De Lange 2012: 586). New elections were held in late January 2003 (Van Holsteyn et al. 2003: 70). To what extent did the participation of the LPF affect the public perception of the two other coalition members, the VVD and CDA?

\section{Weak treatment: the radical right as a support party}

While a majority coalition provides a clear and strong signal to voters about which parties can cooperate, things quickly become more complicated with minority governments, especially externally supported minority governments. Support parties operate in a grey area between opposition and government. There are several reasons why a party might choose to stay out of the coalition: the party might present itself as ideologically opposed to 'politics as usual' or perhaps 'the time is not right' for a new inexperienced party to negotiate with bigger established parties (Bale and Bergman 2006). Due to increased political fragmentation and the antiestablishment profile of many new parties, externally supported minority governments seem to become more common and thus something we need to take into account (Otjes and Louwerse 2014). In this section, I will discuss the Mark Rutte I cabinet in the Netherlands, 2010-12, and the Anders Fogh Rasmussen cabinets (I-III) in Denmark, 2001-11. Other scholars have argued that these governments were majority cabinets in disguise (see Otjes and Louwerse 2014 for the Netherlands and De Lange 2012 for Denmark), but it is unclear whether they were perceived as such by voters, including the corresponding changes to party placement.

In the Dutch 2010 election, the PVV gained more than 15\% of the vote and thus became a key player in the coalition formation process. This resulted in the first Dutch minority government since 1922 (Otjes and Louwerse 2014). Instead of formally joining the VVD and CDA minority government, the three parties created a support agreement with detailed information about which legislation the PVV would support and how it would oppose a motion of no-confidence (De Lange 
2012: 915). The support agreement covered four areas: the budget, immigration, safety and care for the elderly. It also stated that the parties were divided on how to think about Islam. In a separate coalition agreement the CDA and VVD covered all remaining aspects (Otjes and Louwerse 2014: 8-9).

In Denmark, a Liberal-Conservative minority government headed by Anders Fogh Rasmussen took office after the 2001 elections. A coalition between the Liberals $(\mathrm{V})$ and Conservatives $(\mathrm{K})$ was nothing new - the parties had governed together in 1982-93. However, they had always been supported by a combination of the three centre parties. After the 2001 elections, the Liberal-Conservative government relied on the parliamentary support of the DF. This was the first time in the post-war period that a government relied on the parliamentary support of the right wing, and only the third time that a government was formed without the support of the centre parties. Furthermore, the DF suddenly went from having primarily blackmail potential (Downs 1957; Sartori 1976) to having coalition potential (Pedersen 2005). The continuation of the government was a central theme in both the 2005 and the 2007 elections. In 2005 the right-wing bloc maintained its majority, but in 2007 the emergence of a new party, which explicitly opposed the DF, weakened the coalition electorally. Nevertheless, since there was no viable alternative, the coalition stayed in office with the continuing support of the DF (De Lange 2012: 908). The first cabinet (2001-5) was very successful in shifting immigration and integration legislation to the right, while the second and third cabinets made far fewer changes (Akkerman and De Lange 2012: 585). I will examine how the perceptions of the Liberals and Conservatives developed when their cooperation with the DF became more formal and more public.

\section{Methodology}

The empirical analysis stands on three legs. In all cases, I am interested in examining the effect of coalition formation on the perceived ideological position on the participating parties. The challenge is to construct the proper counterfactual. The difference-in-differences $(\mathrm{DiD})$ design is appropriate when some parties experience a change while others do not (Angrist and Krueger 1999: 1296). The treatment effect is measured by comparing the difference in outcomes before and after for the governing parties participating in the coalition with the before and after for opposition parties. The assumption, known as the 'parallel trends' assumption (Xu 2017), is that without the coalition the governing parties would have evolved in parallel with the opposition parties (List and Metcalfe 2014: 588). Naturally, they would have been more right wing but the difference - that is, the party fixed effect - would have been constant over time.

According to comparative research there are only small differences in how mainstream right and mainstream left parties react to the success of radical right parties. They shift their manifesto positions in the same way (Van Spanje 2010; Wagner and Meyer 2017). Thus, it is plausible that deviations in perceptions can be attributed to coalition formation.

First, I utilize a Dutch individual-level panel study conducted around the 2002 and 2003 elections. The panel study allows me to compare the perceptions of the same individual before and after coalition formation - thus I can control for all 
the respondent-level covariates simply by using fixed effects. With a DiD design, I examine whether individual respondents perceived the mainstream right VVD and CDA to converge towards the LPF on immigration issues after the three parties formed a coalition, and likewise, whether they perceived the LPF to converge to the mainstream right on the left/right dimension.

The Dutch Parliamentary Election Study (DPES) 2002-3 consisted of three waves. In the pre-election phase 1,907 face-to-face interviews were conducted between 18 April and 14 May 2002. ${ }^{1}$ The election was held on 15 May and the 1,574 post-election interviews started the day after and continued until 27 June. Respondents in the two surveys were asked to place parties on a different set of issue scales. After the 2003 election, and after the coalition with the LPF was formed and fell, $81 \%$ of the participants from the 2002 post-election study were re-interviewed. This time they were asked to place parties on the left/right dimension and on two issues related to immigration, one from the pre-election and one from the post-election wave. The questionnaire asked:

- Allowing asylum-seekers to enter the Netherlands has frequently been in the news during the last few years. Some people think that the Netherlands should allow more asylum-seekers than the government currently does [number 1]. Other people think that the Netherlands should send asylum-seekers who are already staying here back to their country of origin [number 7].

- There is disagreement in the Netherlands about foreigners and ethnic minorities. Some people and parties think that these people should be able to live in the Netherlands while preserving all customs of their own culture [number 1]. Others think that these people, if they stay in the Netherlands, should completely adjust themselves to Dutch culture [number 7].

Unfortunately, participants were not asked to evaluate party positions on any economic issues in the post-election wave. Thus I am unable to test the third hypothesis in this study.

Second, I conduct a similar analysis using the support agreement between the VVD, CDA and PVV after the 2010 election as the treatment in my DiD design. Since there is no panel data collected before and after coalition formation, I will have to compare party placement in the DPES 2010 and DPES 2012 and use a host of demographic variables as controls. More specifically, I control for respondent self-placement, age, gender, education, self-reported interest in politics and how often the respondent reads a national newspaper.

An issue scale concerning multiculturalism (see above) and one concerning economic redistribution reoccurred in the two surveys: ${ }^{2}$

- Some people and parties think that the differences in incomes in our country should be increased [number 1]. Others think that these differences should be decreased [number 7].

Last, I examine long-term effects in Denmark of exposing voters to the weak coalition treatment over a full decade by using the generalized synthetic control method (GSCM) (Xu 2017). The GSCM is essentially a generalization of the 
DiD design, but has the great advantage that it does not assume random intervention. In other words, it relaxes the 'parallel trends' assumption (Xu 2017). The method solves the problem that a unit (here a mainstream right party) experiences treatment (here coalition formation) at a certain point in time, without there being a comparable case to use as a counterfactual. The solution is to create artificial cases by weighing a set of comparison units.

The untreated comparison units, here parties, make up a donor pool (Abadie et al. 2015). Using a set of predictor variables, the algorithm assigns different weights to each donor in order to approximate the trend in party placements before the intervention. This synthetic control then matches the treated unit in the pretreatment period but will diverge afterwards if the treatment has any effect. In contrast to the standard synthetic control method (Abadie et al. 2015), GSCM uses fixed effects for units so it is not a problem that the two treated units, Liberals and Conservatives, are located on one side of the political spectrum (Xu 2017).

Data are derived from the Danish National Election Study (DNES) 1994-2015. Seven parties were featured continuously over this period: Liberals (V), Conservatives (K), Christian-Democrats (KD), Social Liberals (RV), Social Democrats (SD), Socialist (SF) and the Red-Green Unity List (EL). The radical right DF was not included in the election study prior to 1998. Because of this shorter pre-treatment period I cannot construct an accurate synthetic control, and hence it is not possible to test Hypotheses 1 and 3. This study is thus exclusively focused on the impact of cooperation on the perceived positions of the mainstream right.

Since I need control units that were measured on exactly the same variables, I have to construct the donor pool from the five Danish opposition parties which were consistently included in the national election study. The priority has been to maximize the number of parties in the donor pool, rather than systematically choosing comparative units. It is admittedly a strong assumption that the opposition parties in the donor pool are completely unaffected by the treatment. The parties were placed along these issue dimensions: ${ }^{3}$

- The parties disagree on how many refugees we can receive. Some think we receive far too many [number 1]. Others say we can easily take more refugees [number 5].

- The parties also disagree how large the public sector should be. Some parties say we should cut public revenues and expenditures [number 1]. Others say that we must face increasing public revenues and expenditures [number 5].

For both the DPES and the DNES all issue scales and the left/right dimension have been rescaled to 0 to 1 and recoded such that higher values indicate the more 'restrictive' position taken by the radical right.

\section{Controlling for strategic repositioning}

Before Fortuyn changed the political arena, the VVD had already made a draft that was practically neutral towards multiculturalism (defending classical liberal values such as personal freedom and individual responsibility), but it radically changed its position in January 2002 (Pellikaan et al. 2003: 39-40). Similarly, it should not 
come as a complete surprise to Danish voters that the Danish mainstream right coalition ended up relying on the support of the DF. Both V and K had already started to shift on the immigration issues after the 1993 election and had been on a decade-long journey towards the right before they formed the coalition (De Lange 2012: 910). Thus, it becomes an important question whether the coalition formation caused a direct or an indirect change in public perceptions of party positions. Was the shift in voters' perceptions only due to shifts in policy platforms? Or was there an independent effect of coalition participation in itself?

The most important control variable is the explicit ideological distance that parties, strategically or otherwise, try to portray. Like most of the previous research, I rely on data from the Manifesto Research on Political Representation (MARPOR) (see e.g. Adams et al. 2016; Fortunato and Adams 2015; Fortunato and Stevenson 2013a). In both Dutch cases, a new election is held prematurely such that the coalition formation is framed by two elections within a relatively short time interval. This allows me to use two different MARPOR data points to estimate explicit ideological positions before and after.

Unfortunately, this approach is not ideal when it comes to more specific issues. First of all, the match between MARPOR categories and issues included in the DPES and DNES is far from perfect. The MARPOR coding scheme is not designed for capturing radical right discourse. The 56 individual issue categories are not fully reliable and there is not a specific category capturing immigration (Protsyk and Garaz 2013). More generally, it can be problematic to rely too much on individual MARPOR categories, because they tend to be very noisy measures (Mikhaylov et al. 2012). Nevertheless, the manifesto positions are the only measures that so closely track these specific elections and allow me to measure the explicit ideological positions of parties both before and after the coalition formation. Being able to control for changes in explicit party positions over this exact period is absolutely crucial for the empirical strategy outlined above, and thus I include MARPOR data in all three analyses despite its various shortcomings. A detailed description of the measures used can be found in the online Appendix.

While MARPOR data cover all of the elections in this analysis, the alternatives are much more limited. There is the Chapel Hill Expert Survey (CHES), conducted approximately every four years in 1999-2014. Because the waves are so far apart, they are not suitable for analysing differences between the 2002 and 2003 elections or the 2010 and 2012 elections. However, the CHES can be used to fit the synthetic control in the Danish case. While more recent waves of the CHES include very specific issue questions, the earliest waves only have very broad categories: GALTAN, which captures the position of the party in terms of their views on democratic freedoms and rights, and LRECON, which captures the position of the party in terms of its ideological stance on economic issues (Bakker et al. 2015).

\section{Results}

\section{Study 1: short-term effects of strong treatment}

In the first study, I simply explore whether coalition formation had an impact on how voters subsequently placed the two mainstream governing parties, the VVD 
and CDA, and the radical right LPF on a number of issue scales. Following the notation in Joshua Angrist and Alan Krueger (1999: 1299), the observed placement by individual $i$ of party $j$ at time $t$ absent the coalition formation is estimated as a function of party effects that are fixed over time and a year effect that is common for all parties. The effect of the coalition is simply to add a constant, the treatment effect, here denoted as $\delta$. The interaction term year ${ }^{*}$ party is equivalent to a dummy that equals 1 if the party was exposed to the treatment. The manifesto position is specific to both year and party and controls for any indirect effects of coalition formation that might have caused parties to change explicit and strategic positions. Finally, $\lambda_{i}$ is respondent fixed effects, and ${ }_{i j t}$ is the error term:

$$
\begin{aligned}
\text { placement }_{i j t}= & \beta_{0}+\beta_{1} \text { party }_{j}+\beta_{2} \text { year }_{t}+\delta\left(\text { year } * \text { party }_{j t}+\beta_{3} \text { manifesto }_{j t}\right. \\
& +\lambda_{i}+\in_{i j t}
\end{aligned}
$$

In the DiD design, I compare the change in party placement for mainstream right parties that formed a coalition with the LPF to the same change for mainstream left parties that did not. For this design to provide the effect of coalition formation, the change for control parties must provide an accurate estimate of how the mainstream right parties would have changed if the LPF was not included in the coalition. In other words, I assume that the difference between the mainstream right and the mainstream left would have been constant had it not been for the treatment. Absent the coalition treatment, party placement would have been a function of respondent-specific idiosyncratic effects, the time, whether the party was mainstream right and the party's ideological platform represented by the party manifesto. The baseline in this analysis varies by issue. For the left/right dimension, all seven opposition parties (PvdA, GL, SP, D66, CU, SGP and LN) are included in the baseline. For the multiculturalism issue, the baseline is the mainstream left parties D66 and PvdA and the green party GroenLinks (GL), and for asylum it is only the D66 and PvdA. ${ }^{4}$

According to the hypotheses, there should be a significant negative treatment effect of being the LPF after the coalition on the left/right dimension and a significant positive treatment effect of being a mainstream right party after the coalition formation on the immigration issues.

In Table 1 one sees that there are significant treatment effects across the board for the mainstream right parties, but not for the radical right. The CDA and VVD are on average perceived as 0.14 units to the right of the opposition on the left/right dimension, while they are perceived as 0.19 units more restrictive towards granting asylum to refugees and 0.26 units more opposed to multiculturalism. As we would expect, the LPF is even further to the right on all scales. This is all after taking manifesto positions into account.

After the treatment, in 2003, the opposition parties are perceived as further to the left on all scales. In all models, the baseline effects of 2003 are so strong that despite a significant treatment effect, there is no significant total effect of the coalition formation. In other words, despite all the other parties moving to the left, the right-wing parties maintained their positions.

On the left/right dimension there is a strong positive and significant treatment effect for both mainstream parties and the radical right. Contrary to Hypothesis 1, 
Table 1. Party Placement Before/After Coalition Formation, 2002

\begin{tabular}{|c|c|c|c|}
\hline & Left/right & Asylum & Multiculturalism \\
\hline Mainstream right (dummy) & $0.140^{\star \star \star}(0.005)$ & $0.191^{\star \star \star}(0.004)$ & $0.264^{\star \star \star}(0.005)$ \\
\hline LPF (dummy) & $0.205^{\star \star \star}(0.006)$ & $0.385^{\star \star \star}(0.006)$ & $0.390^{\star \star *}(0.008)$ \\
\hline 2003 (dummy) & $-0.140^{\star \star \star}(0.003)$ & $-0.097^{\star \star \star}(0.005)$ & $-0.048^{\star \star \star}(0.006)$ \\
\hline 2003 * mainstream right & $0.070^{\star \star \star}(0.006)$ & $0.078 \quad(0.006)$ & $0.044^{\star \star \star}(0.006)$ \\
\hline $2003 *$ LPF & $0.106^{\star \star \star}(0.008)$ & $0.001 \quad(0.007)$ & $0.055^{\star \star \star}(0.008)$ \\
\hline Manifesto position & $0.831^{\star \star \star}(0.014)$ & $4.006^{\star \star \star}(0.126)$ & $2.462^{\star \star \star}(0.137)$ \\
\hline Observations & 35,183 & 21,197 & 21,427 \\
\hline $\mathrm{R}^{2}$ & 0.378 & 0.615 & 0.588 \\
\hline Adjusted $\mathrm{R}^{2}$ & 0.325 & 0.548 & 0.526 \\
\hline
\end{tabular}

Note: ${ }^{*} \mathrm{p}<0.1 ;{ }^{* \star} \mathrm{p}<0.05 ;{ }^{* \star} \mathrm{p}<0.01$.

the results suggest that the VVD, CDA and the LPF were perceived as slightly further to the right than they would have been if they had not joined a coalition together. This also runs directly counter to previous findings by Fortunato and Adams (2015) that showed that the perceptions of the prime minister's party were largely unaffected by coalition formation, while the junior member was perceived as largely adopting the prime minister's position. The mainstream parties were less affected than the LPF.

On the question of asylum, we see that the two mainstream right parties were perceived as 0.08 units more restrictive on the issue scale than they would have been otherwise, because of the coalition with the LPF. Without the treatment, all the parties in the system would have moved 0.1 units towards more permissive positions. Hence, there is a net positive change between 2002 and 2003 for both governing and opposition parties. Note that there is no substantial policy anchoring the scales. The results could indicate that the use of the scale changed radically between the two elections: the discourse on immigration policies shifted during 2002, and positions that were previously considered radical became normalized. The key takeaway should be that there was a positive treatment effect for the mainstream right, and thus that including the radical right did have a strong significant impact on how the mainstream right parties were perceived by voters relative to other parties. The interesting movements over time are relative, not absolute. In short, these coefficient estimates provide strong support for Hypothesis 2.

There is a similar effect on the related question of multiculturalism. Here the treatment effect is 0.04 for the mainstream right, indicating that the mainstream right were perceived as significantly more opposed to multiculturalism than they would have been otherwise. Surprisingly, there is an even larger effect for the LPF. Why is there a difference in the results between two seemingly related issues? The devil is in the detail and one should be careful when making general claims about the 'immigration issue'. A careful observer of Dutch politics would argue that the two issues are in fact not so similar (Akkerman et al. 2016). Specifically on the issue of asylum the LPF was more moderate than the VVD at the end of the 2002 campaign. 
That there are somewhat different results between the asylum and the multiculturalism issues might raise concerns that the treatment on the asylum issue is confounded. Pim Fortuyn was assassinated merely seven days before the election, after most of the responses for party placement on the issue of granting asylum to refugees were collected. Perhaps it was his murder, not the entry of the LPF into parliament and/or the governing coalition, that caused a major change in voter perceptions (Bischof and Wagner 2019). By looking only at individuals who answered the pre-election survey after the murder, I can establish that the effect is not solely due to the assassination. The online Appendix shows the results.

When examining the subset that answered the survey after the assassination of Pim Fortuyn one also sees that the pre-treatment 2002 perception of the LPF is slightly more moderate. Elias Dinas et al. (2016) showed that the murder itself generated a surge in sympathy for the LPF which motivated survey respondents to place the party much closer to their own positions on the issues of asylum-seekers, crime, economic redistribution and euthanasia. For this subset there is a positive and significant treatment effect, suggesting that the LPF was not perceived as moderating very much after joining the coalition.

All in all, I find mixed support for the first and second hypotheses. I cannot test the third hypothesis in this analysis, since there were no strictly economic issues included in both surveys.

\section{Study 2: short-term effects of weak treatment}

The second study explores whether the support agreement between the VVD, CDA and the PVV impacted how voters placed the relevant parties on immigration and economic issues. According to the hypotheses, there should be a negative treatment effect for the PVV on the left/right scale, moving the PVV to the left, and a positive effect on the redistribution issue, moving the PVV to the right. Meanwhile, there should be a positive treatment effect for the mainstream parties on multiculturalism, such that the parties are perceived as more restrictive after joining a coalition with the PVV. The baseline in this analysis is the opposition parties PvdA, D66 and the Socialist Party (SP), except for on the general left/right where the GL is also included. The observed placement by individual $i$ of party $j$ at time $t$ is estimated with the following equation, where the interaction term year ${ }^{\star}$ party is equivalent to a dummy for exposure to the treatment, $\delta$ is the treatment effect and ${ }_{i j t}$ is the error term:

$$
\begin{aligned}
\text { placement }_{i j t}= & \beta_{0}+\beta_{1} \text { part }_{j}+\beta_{2} \text { year }_{t}+\delta\left(\text { year } * \text { party }_{j t}+\beta_{3} \text { manifesto }_{j t}\right. \\
& +\vec{\beta}_{4} \text { demographics }+\in_{i j t}
\end{aligned}
$$

Table 2 shows that, after taking manifesto positions into account, the mainstream right is still perceived as further right on the left/right dimension and more negative towards multiculturalism and economic redistribution than the baseline parties. Surprisingly, the PVV is perceived as less restrictive towards multiculturalism but more opposed to redistribution and generally further right than is indicated by the party's manifesto.

There are strong treatment effects on all issues for both mainstream and radical right. I find the expected relationship on the general left/right dimension. There is a 
Table 2. Party Placement Before/After the Support Agreement, 2010

\begin{tabular}{|c|c|c|c|c|}
\hline \multirow[b]{2}{*}{ Mainstream right (dummy) } & \multicolumn{2}{|c|}{ Left/right } & \multirow{2}{*}{$\begin{array}{l}\text { Multiculturalism } \\
0.046^{\star \star \star}(0.006)\end{array}$} & \multirow{2}{*}{$\begin{array}{c}\text { Redistribution } \\
0.182^{\star \star \star}(0.006)\end{array}$} \\
\hline & $0.178^{\star \star \star}$ & $(0.006)$ & & \\
\hline PVV (dummy) & $0.308^{\star \star \star}$ & $(0.007)$ & $-0.228^{\star \star \star}(0.030)$ & $0.168^{\star \star \star}(0.007)$ \\
\hline 2012 (dummy) & $0.095^{\star \star \star}$ & $(0.004)$ & $-0.057^{\star \star \star}(0.006)$ & $0.142^{\star \star \star}(0.007)$ \\
\hline 2012 * mainstream right & $-0.167^{\star \star \star}$ & $(0.007)$ & $0.065^{\star \star \star}(0.008)$ & $-0.136^{\star \star \star}(0.009)$ \\
\hline 2012 * PVV & $-0.200^{\star \star \star}$ & $(0.009)$ & $0.067^{\star \star \star}(0.011)$ & $-0.263^{\star \star \star}(0.013)$ \\
\hline Manifesto position & $1.762^{\star \star \star}$ & $(0.041)$ & $4.534^{\star \star \star}(0.185)$ & $2.652^{\star \star \star}(0.101)$ \\
\hline Respondent self-placement & 0.0003 & $(0.006)$ & $0.138^{\star \star \star}(0.007)$ & $0.122^{\star \star \star}(0.008)$ \\
\hline Age & $0.0003^{\star \star \star}$ & $(0.0001)$ & $0.001^{\star \star \star}(0.0001)$ & $-0.0002 \quad(0.0001)$ \\
\hline Female & -0.002 & $(0.003)$ & $0.014^{\star \star \star}(0.004)$ & $-0.001 \quad(0.004)$ \\
\hline Lower vocational education & -0.008 & $(0.007)$ & $-0.056^{\star \star \star}(0.009)$ & $-0.027^{\star \star \star}(0.009)$ \\
\hline Secondary education & 0.002 & $(0.008)$ & $-0.030^{\star \star \star}(0.011)$ & $-0.043^{\star \star \star}(0.011)$ \\
\hline $\begin{array}{l}\text { Middle vocational/higher } \\
\text { secondary }\end{array}$ & -0.002 & $(0.007)$ & $-0.037^{\star \star \star}(0.009)$ & $-0.023^{\star \star \star}(0.009)$ \\
\hline $\begin{array}{l}\text { Higher vocational/university } \\
\text { education }\end{array}$ & 0.007 & $(0.007)$ & $-0.020^{\star \star} \quad(0.009)$ & $-0.033^{\star \star \star}(0.009)$ \\
\hline Self-reported political interest & $0.014^{\star \star}$ & $(0.005)$ & $-0.010 \quad(0.007)$ & $0.0004 \quad(0.007)$ \\
\hline Newspaper reading & -0.001 & $(0.004)$ & -0.007 & $0.008 \quad(0.005)$ \\
\hline Constant & $-0.472^{\star \star \star}$ & $(0.020)$ & $-1.792^{\star \star \star}(0.089)$ & $-1.549^{\star \star \star}(0.071)$ \\
\hline Observations & 22,6 & & 15,838 & 19,270 \\
\hline $\mathrm{R}^{2}$ & 0.47 & & 0.404 & 0.219 \\
\hline Adjusted $\mathrm{R}^{2}$ & 0.47 & & 0.403 & 0.218 \\
\hline
\end{tabular}

Note: ${ }^{\star} \mathrm{p}<0.1 ;{ }^{\star \star} \mathrm{p}<0.05 ;{ }^{\star \star \star} \mathrm{p}<0.01$

strong treatment effect for the PVV, which is perceived as 0.2 units further to the left after signing the support agreement than it would have been otherwise. However, the mainstream right parties are not unaffected. They too are perceived as moving towards the political centre.

On the questions of multiculturalism, which is certainly the most salient issue for the PVV, there is a moderate positive treatment effect for all three right-wing parties. The three parties are perceived as staying put, while the control parties move 0.06 units further towards permissive positions on the issue after the mainstream right signed the support agreement with the PVV. Again, this could indicate a shift in how the scale is perceived and used. I interpret it as partial support for the second hypothesis. It is noteworthy that the coalition agreement had a substantial effect on multiculturalism even though the three parties had stated explicitly that they disagreed (Otjes and Louwerse 2014).

Finally, there is a significant treatment effect on the issue of redistribution for the PVV, but in the opposite direction. The party is perceived as 0.26 units further to the left than it would have been otherwise, consequently moving it further away 
from the coalition partners. There is also a significant effect for the two mainstream right parties, which are perceived as largely staying put after the coalition formed. As with the two other issues, the picture is that of a right-wing coalition which is moving in parallel instead of approaching each other. The PVV is more heavily affected on the left/right and on redistribution, but the differences between parties are small.

\section{Study 3: long-term effects of weak treatment}

The seven Danish parties in the third analysis are observed in seven election studies over a period of 21 years (1994-2015). All studies are post-election studies, which means that only 1994 and 1998 came before the coalition treatment in 2001. I create time-series data by computing weekly averages of all placements of a party based on response date. Unfortunately, the exact time of data collection is only available for 1994 and 2001, so in all other years I am forced to assume that observations are uniformly distributed over the entire data-collection period and base weekly averages on that. Violating this assumption should not have any substantial effects on the validity of the results. I am looking for change in perceptions between elections and not over the course of the months that the survey is in the field. Calculating weekly averages is a method to generate more pre-treatment observations, not because I expect there to be meaningful trends at that level.

In the previous analysis, the changing perceptions of the mainstream right were compared with the average trend for opposition parties. In short, I examined whether the mainstream right was perceived as moving further away from the opposition on immigration issues after cooperating with the radical right or whether the trends were parallel. Here in this analysis, the goal is to create a synthetic control for the issue position of $\mathrm{V}$ and one for the issue position of $\mathrm{K}$ by taking weighted averages of the five opposition party positions in the donor pool. This combination of parties in the donor pool will do a better job at matching the characteristics of the two parties of interest than comparison to any general baseline (Abadie et al. 2015).

The best possible weights will minimize the sum of absolute distances between the synthetic controls and the treated parties in the pre-treatment period. The algorithm generating these weights is complicated. The most important thing to note is that treated parties and their controls are matched on both the dependent variable that is, perceived party positions - and a number of matching variables, also called predictor variables. Including these variables is equivalent to controlling for them. However, not every variable is equally important. The synthetic control should most closely reproduce the values of variables that are good predictors of the outcome of interest (Abadie et al. 2015).

To estimate that, I specify a number of matching variables where the synthetic controls should mimic the treated mainstream right parties in the pre-treatment period. I used manifesto positions and expert placements to predict perceived party positions. For instance, to create a synthetic control for the perceived position of the Liberals on refugees and asylum I create a synthetic control that matches on manifesto position on asylum and the general left/right and the average placement on the cultural dimension (GALTAN) and the general left/right in an expert survey. 
Table 3. Coefficient Estimates for Perceived Party Position on Asylum

\begin{tabular}{lccccc}
\hline & Beta & S.E. & Cl. lower & Cl. upper & p value \\
\hline Manifesto issue position & 0.45 & 0.04 & 0.46 & 0.61 & 0.00 \\
\hline Manifesto left/right position & 0.24 & 0.03 & 0.15 & 0.27 & 0.00 \\
\hline Expert cultural position & -0.26 & 0.04 & -0.36 & -0.18 & 0.00 \\
\hline Expert left/right position & 1.18 & 0.08 & 0.77 & 1.10 & 0.00 \\
\hline Party size & -0.00 & 0.00 & -0.00 & -0.00 & 0.00 \\
\hline Supporter issue position & -0.48 & 0.04 & -0.53 & -0.36 & 0.00 \\
\hline
\end{tabular}

I also used the average self-placement of respondents who indicated that they identified with the party as a measure of party supporter position. Lastly, I also include party size. Specifically for the asylum issue, the model returns the coefficient estimates displayed in Table 3.

Following Alberto Abadie et al. (2015: 498), the treatment effect for the two treated parties $j \in[1,2]$ in the post-treatment period $t$ is given by the equation below where $\delta$ is the treatment effect and $w$ is a $(J-2 \times 1)$ vector of weights, one for each of the comparison parties in the donor pool:

$$
\delta_{j t}=\text { placement }_{j t}-\sum_{j=3}^{J} w_{j} \text { placement }_{j t}
$$

Figure 1 graphs the average treatment effect on the treated (ATT), on the question of asylum. Since there are two treated parties, it is possible to average the treatment effect to summarize the main result. The graph shows the difference between the reported perceptions of party positions and the estimated counterfactual in every observed week after the coalition formation $(t=0)$. There is a significant positive effect on the two mainstream right parties between the 40th and the 80th time point after the treatment. In other words, the Liberals and Conservatives were perceived as more restrictive towards refugees and asylum-seekers than they would have been otherwise. Over time the ATT slowly starts to creep downwards again and approaches 0 . By the end of the period, the Conservatives and the Liberals were again following the same trend as the opposition parties that had been similar to them before 2001 .

The same relationship is illustrated in Figure 2. The figure plots the average of treated units and their estimated synthetic controls. The figure also plots the raw data. One sees that observations are clustered around the seven elections and that all of the 'real-life' controls are found at lower values because the opposition parties are much more positive towards immigrants. This shows that the estimated synthetic control was slightly higher than the treated units in 2001, but then quite a lot smaller in 2005, 2007 and 2011. This result suggests that the two mainstream right parties were indeed perceived as more critical towards refugees after the coalition formation supported by the DF.

Figures 3 and 4 also show the average of treated units and synthetic controls, but on the issue of public spending versus tax and on the general left/right dimension. 


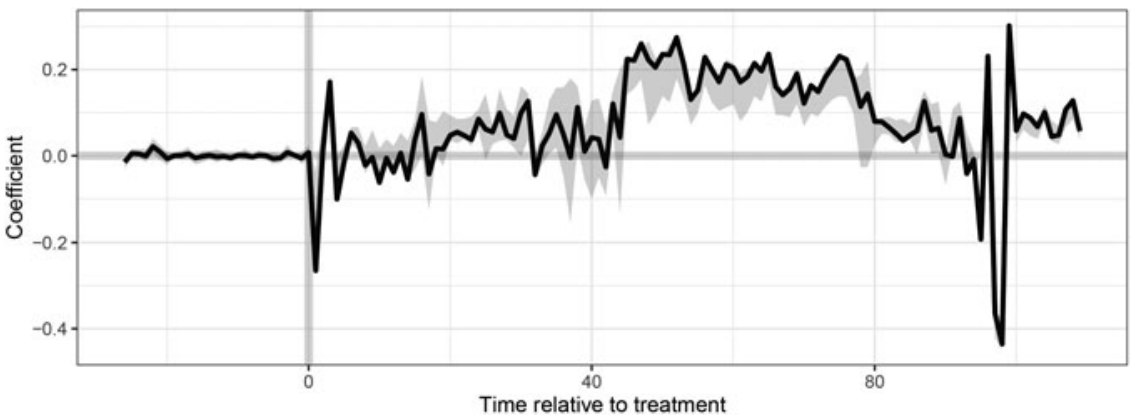

Figure 1. Generalized Synthetic Control Estimates: Average Treatment Effect of Coalition Formation on the Mainstream Right

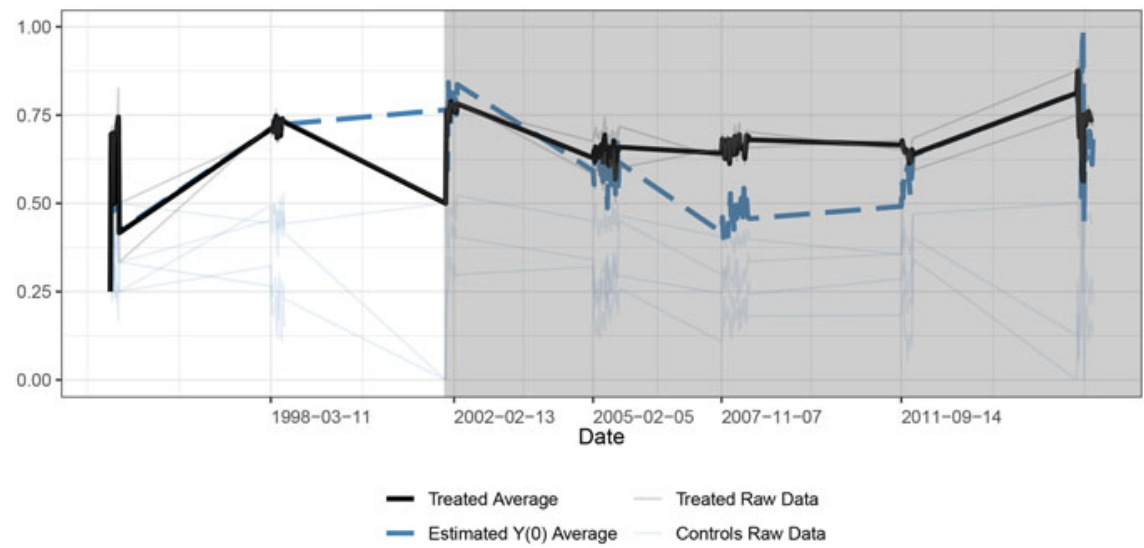

Figure 2. Outcome and Counterfactual Perceptions of Positions on Asylum on Mainstream Right after Coalition Formation

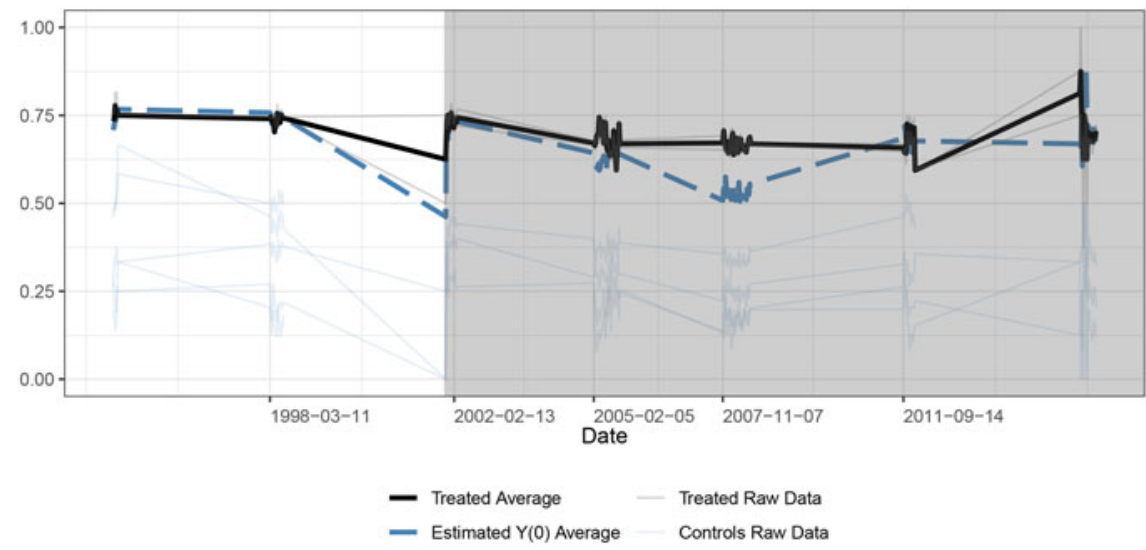

Figure 3. Outcome and Counterfactual Perceptions of Positions on Public Spending on the Mainstream Right after Coalition Formation 


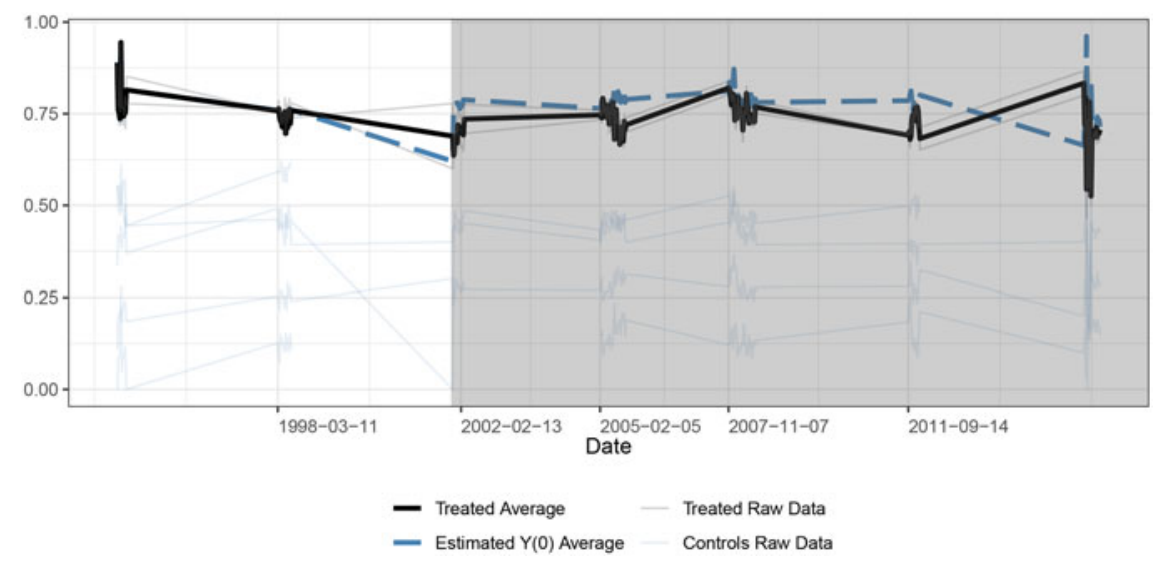

Figure 4. Outcome and Counterfactual Perceptions of Positions on General Left/Right Dimension on the Mainstream Right after Coalition Formation

According to the hypotheses there should not be any significant effect of cooperation with the radical right for the mainstream parties on public perceptions on this economic issue scale, since the mainstream parties are in charge of this policy area, or on the overarching left/right. The model reveals that there are some effects but that they are smaller and shorter lived.

The year 2005 is the first election after the DF started supporting the mainstream right-wing coalition. Here there is practically no difference between the perceived economic position of the treated parties and the synthetic controls. Immediately after the 2007 election, the mainstream right was perceived as more right-wing on public spending than they would have been otherwise, but in 2011 and 2015 the effect is gone again.

On the left/right dimension in Figure 4, the two parties are generally thought of as more moderate than would have been expected. In 2005 and 2007, the dashed line representing the average perception of the synthetic control is slightly above the treated average. However, these differences are hardly of any practical significance. In 2011 and 2015, the two lines are almost impossible to distinguish.

Table 4 summarizes the results of the GSCM for all three issue scales. The treatment effect is averaged across all treated parties and all post-treatment periods, and thus represents a one-figure summary of the effect of coalition formation on voters' perceptions of party positions. In other words, it is the difference between the factual and counterfactual perceived positions across points in time and the two parties in the study. As expected, there is a positive effect on the issue of asylum and refugees, meaning that the mainstream right parties on average were perceived as much more restrictive towards immigration after the coalition formation than they would have been otherwise. This result provides strong support for Hypothesis 2. There is also a small positive effect on the issue of public spending and an even smaller negative effect on the left/right dimension. These two results are not explained by the existing theory. All the estimates are significant at the $\alpha=0.001$ level. 
Table 4. ATT Averaged Over All Periods

\begin{tabular}{lccccc}
\hline & Treatment effect & S.E. & Lower bound & Upper bound & $p$ value \\
\hline Asylum & 0.0819 & 0.008 & 0.0588 & 0.0922 & 0.000 \\
\hline Public spending & 0.0572 & 0.0141 & 0.0157 & 0.0714 & 0.002 \\
Left/right & -0.0461 & 0.0010 & -0.0486 & -0.0447 & 0.000 \\
\hline
\end{tabular}

\section{Discussion}

A great deal of recent literature in the field of party competition has been devoted to studying what happens to radical right parties and their reputations when they start cooperating with the establishment. Few scholars have paid any attention to the trade-offs facing mainstream parties. Radical right parties represent attractive coalition partners because their preferences are to a large extent tangential to those of mainstream parties. That means that the parties can engage in log-rolling and delegate control to the parties that attach more salience to the respective economic and immigration issues. However, when engaging in this strategy, mainstream parties naturally risk being accused of selling out on the issue of the radical right.

In this article, I hypothesize that all coalition members will be perceived as taking policy positions that are closer to the position of the party that attributes most salience to an issue. More specifically, I propose that the immigration positions of the radical right will rub off on their mainstream parties. In turn, the perceptions of the radical right on economic issues will start to approach that of the mainstream right. I test my hypothesis on data from a strong (2002) and a weak (2010) coalition treatment in the Netherlands, as well as on the long-term evolution of voter perceptions of Danish parties (1994-2015).

I find mixed support for my hypotheses. The perceptions of the VVD's and CDA's positions on the issue of asylum were certainly tainted after their coalition with the LPF in 2002, but the perception of their position on multiculturalism less so. The perceptions of the VVD and CDA were also affected by the weak coalition treatment when they signed a support agreement with the PVV in 2010. In line with my hypothesis, the two mainstream right parties were perceived as moving towards the PVV on immigration and multiculturalism, holding everything else constant. Contrary to my hypothesis, the voters' perceptions of the radical right moved too. Similarly, I generally found that all coalition partners moved in unison on the economic issues and on the left/right dimension. Lastly, the analysis of longterm trends in Denmark using GSCM shows that the mainstream right governing parties were strongly affected by the radical right support when it comes to asylum and refugees, but also to some extent on the issue of spending in the public sector.

I have so far found more support for the second hypothesis about immigration issues than for the first hypothesis about the general left/right and the third hypothesis about economic issues. Admittedly, between 0.05 and 0.10 on a 0 to 1 scale might not sound like a practically significant effect. However, recall that both the Danish and the Dutch party systems are rather crowded. Survey respondents are tasked with placing 8-13 parties on an 11-point scale. Perceived ideological 
movements of half a unit might imply that parties are leap-frogging each other or have substantive consequences for which party is perceived as more proximate to the voter.

The results suggest that voters are grouping coalition partners together on various issues, but that perceptions are often moving in parallel rather than approaching each other. This matches previous results, which have found that instead of moderating on the immigration issue, the radical right has moved even further to the right such that the gap remains intact (Akkerman et al. 2016; Wagner and Meyer 2017) and adds to the mounting evidence against the inclusion-moderation thesis. Whether the radical right parties' ability to maintain a distinct profile on the immigration issue is caused by their somewhat informal cooperation with the mainstream right, as opposed to formal coalition membership, is certainly a hypothesis worth exploring further.

These three studies offer some variation in terms of the political context and the policy issues studied, but more work is needed to establish the generalizability of the claims. The argument is not limited to radical right parties, but could also apply to situations with smaller differences in issue emphasis. The theory suggests that voters assume that, when bargaining over the coalition policy, parties have a larger say on the issues they care deeply about. A more direct way of testing the effect of perceived policy influence is to examine whether voters project the issue position of the minister responsible for a given policy onto all other members of the coalition. If this is the case, then cabinet leaders could strategically change the policy image of the entire coalition without any of the actors changing their stated policy, simply by shuffling portfolios.

This article takes the important first step, in theorizing about how cooperation with niche parties will affect voter perceptions of party positions. As Western European party systems are becoming more fragmented, we are likely to witness even more radical right parties or other types of niche parties in government. Any coalition formation or support agreement between parties with complementary policy would represent a valuable case for testing the hypotheses outlined in this article.

Supplementary material. To view the supplementary material for this article, please go to: https:/doi. org/10.1017/gov.2020.28.

Acknowledgements. The author would like to thank Herbert Kitschelt, Christopher Johnston, Christoffer Green Pedersen, Jelle Koedam and the three anonymous reviewers for their valuable feedback.

\section{Notes}

1 A few alterations were made after the assassination of Pim Fortuyn on 6 May, but nothing that directly affected the items of interest.

2 All Dutch surveys included batteries asking about party positions on the issue of EU integration, and in 2010-12 there were batteries concerning euthanasia. The theory does not provide any clear hypotheses on these issues, so they are not included in the main analysis. Results are provided in the online Appendix. 3 There are also issue scales for law and order and environmental policy, but given that there are no clear theoretical expectations for these issues they are only featured in the online Appendix.

4 Groen Links was not included in the 2002 pre-election survey and is thus not part of the baseline on the asylum question. The SP, CU, SGP and LN were only included in the survey battery concerning left/right placement. 


\section{References}

Abadie A, Diamond A and Hainmueller J (2015) Comparative Politics and the Synthetic Control Method. American Journal of Political Science 59(2), 495-510. https://doi.org/10.1111/ajps.12116.

Abou-Chadi T (2016) Niche Party Success and Mainstream Party Policy Shifts - How Green and Radical Right Parties Differ in their Impact. British Journal of Political Science 46(2), 417-436. https://doi.org/10. 1017/S0007123414000155.

Abou-Chadi T and Krause W (2020) The Causal Effect of Radical Right Success on Mainstream Parties' Policy Positions: A Regression Discontinuity Approach. British Journal of Political Science 50(3), 829847. https://doi.org/10.1017/S0007123418000029.

Adams J, Ezrow L and Wlezien C (2016) The Company You Keep: How Voters Infer Party Positions on European Integration from Governing Coalition Arrangements. American Journal of Political Science 60 (4), 811-823. https://doi.org/10.1111/ajps.12231.

Akkerman T (2015) Immigration Policy and Electoral Competition in Western Europe: A Finegrained Analysis of Party Positions Over the Past Two Decades. Party Politics 21(1), 54-67. https://doi.org/10. $1177 / 1354068812462928$.

Akkerman T and De Lange SL (2012) Radical Right Parties in Office: Incumbency Records and the Electoral Cost of Governing. Government and Opposition: An International Journal of Comparative Politics 47(4), 574-596. https://doi.org/10.1111/j.1477-7053.2012.01375.x.

Akkerman T and Rooduijn M (2015) Pariahs or Partners? Inclusion and Exclusion of Radical Right Parties and the Effects on their Policy Positions. Political Studies 63(5), 1140-1157. https://oi.org/10. 1111/1467-9248.12146.

Akkerman T, De Lange S and Rooduijn M (eds) (2016) Radical Right-Wing Populist Parties in Western Europe: Into the Mainstream? Abingdon: Routledge.

Angrist JD and Krueger AB (1999) Empirical Strategies in Labor Economics. In Ashenfelter O and Card D (eds), Handbook of Labor Economics, Vol. 3. Amsterdam: Elsevier, pp. 1277-1366.

Bäck H, Debus M and Dumont P (2011) Who Gets What in Coalition Governments? Predictors of Portfolio Allocation in Parliamentary Democracies. European Journal of Political Research 50(4), 441478. https://doi.org/10.1111/j.1475-6765.2010.01980.x.

Bakker R, De Vries C, Edwards E, Hooghe L, Jolly S, Marks G, Polk J, Rovny J, Steenbergen M and Vachudova MA (2015) Measuring Party Positions in Europe: The Chapel Hill Expert Survey Trend File, 1999-2010. Party Politics 21(1), 143-152. https://doi.org/10.1177/1354068812462931.

Bale T and Bergman T (2006) A Taste of Honey is Worse than None at All? Coping with the Generic Challenges of Support Party Status in Sweden and New Zealand. Party Politics 12(2), 189-202. https://doi.org/10.1177/1354068806061337.

Bischof D and Wagner M (2019) Do Voters Polarize when Radical Parties Enter Parliament? American Journal of Political Science 63(4), 888-904. https://doi.org/10.1111/ajps.12449.

Bos L and van der Brug W (2010) Public Images of Leaders of Anti-Immigration Parties: Perceptions of Legitimacy and Effectiveness. Party Politics 16(6), 777-799. https://doi.org/10.1177/1354068809346004.

Brubaker R (2017) Between Nationalism and Civilizationism: The European Populist Moment in Comparative Perspective. Ethnic and Racial Studies 40(8), 1191-1226. https://doi.org/10.1080/ 01419870.2017.1294700.

Budge I and Farlie D (1983) Explaining and Predicting Elections: Issue Effects and Party Strategies in Twenty-Three Democracies. Winchester: Allen and Unwin.

De Lange SL (2012) New Alliances: Why Mainstream Parties Govern with Radical Right-Wing Populist Parties. Political Studies 60(4), 899-918. https://doi.org/10.1111/j.1467-9248.2012.00947.x.

De Swaan A (1973) Coalition Theories and Cabinet Formations: A Study of Formal Theories of Coalition Formation Applied to Nine European Parliaments After 1918, Vol. 4. Amsterdam: Elsevier.

Dennison J and Geddes A (2019) A Rising Tide? The Salience of Immigration and the Rise of Anti-Immigration Political Parties in Western Europe. Political Quarterly 90(1), 107-116. https://doi. org/10.1111/1467-923X.12620.

Dinas E, Hartman E and van Spanje J (2016) Dead Man Walking: The Affective Roots of Issue Proximity Between Voters and Parties. Political Behavior 38(3), 659-687. https://doi.org/10.1007/s11109-016-9331-2.

Downs A (1957) An Economic Theory of Democracy. New York: Harper. 
Downs WM (2001) Pariahs in their Midst: Belgian and Norwegian Parties React to Extremist Threats. West European Politics 24(3), 23-42. https://doi.org/10.1080/01402380108425451.

Fernandez-Vazquez P (2014) And Yet it Moves: The Effect of Election Platforms on Party Policy Images. Comparative Political Studies 47(14), 1919-1944. https://doi.org/10.1177/0010414013516067.

Fortunato D and Adams J (2015) How Voters' Perceptions of Junior Coalition Partners Depend on the Prime Minister's Position. European Journal of Political Research 54(3), 601-621. https://doi.org/10. 1111/1475-6765.12094.

Fortunato D and Stevenson RT (2013a) Perceptions of Partisan Ideologies: The Effect of Coalition Participation. American Journal of Political Science 57(2), 459-477. https://doi.org/10.1111/j.15405907.2012.00623.x.

Fortunato D and Stevenson RT (2013b) Performance Voting and Knowledge of Cabinet Composition. Electoral Studies 32(3), 517-523. https://doi.org/10.1016/j.electstud.2013.05.001.

Han KJ (2015) The Impact of Radical Right-Wing Parties on the Positions of Mainstream Parties Regarding Multiculturalism. West European Politics 38(3), 557-576. https://doi.org/10.1080/01402382. 2014.981448 .

Hjermitslev IB (2020) The Electoral Cost of Coalition Participation: Can Anyone Escape? Party Politics 26 (4), 510-520. https://doi.org/10.1177/1354068818794216.

Laver M and Schofield N (1998) Multiparty Government: The Politics of Coalition in Europe. Ann Arbor: University of Michigan Press.

List JA and Metcalfe R (2014) Field Experiments in the Developed World: An Introduction. Oxford Review of Economic Policy 30(4), 585-596. https:/doi.org/10.1093/oxrep/grv005.

Luebbert GM (1986) Comparative Democracy: Policymaking and Governing Coalitions in Europe and Israel. New York: Columbia University Press.

Meguid BM (2005) Competition Between Unequals: The Role of Mainstream Party Strategy in Niche Party Success. American Political Science Review 99(3), 347-359. https://doi.org/10.1017/S0003055405051701.

Mikhaylov S, Laver M and Benoit KR (2012) Coder Reliability and Misclassification in the Human Coding of Party Manifestos. Political Analysis 20(1), 78-91. https://doi.org/10.1093/pan/mpr047.

Mudde C (2007) Populist Radical Right Parties in Europe, Vol. 22. Cambridge: Cambridge University Press.

Otjes S and Louwerse T (2014) A Special Majority Cabinet? Supported Minority Governance and Parliamentary Behavior in the Netherlands. World Political Science 10(2), 343-363. https://doi.org/10. 1515/wpsr-2014-0016.

Pedersen K (2005) The 2005 Danish General Election: A Phase of Consolidation. West European Politics 28 (5), 1101-1108. https://doi.org/10.1080/01402380500311848.

Pellikaan H, van der Meer T and De Lange S (2003) The Road from a Depoliticized to a Centrifugal Democracy. Acta Politica 38(1), 23-49. https://doi.org/10.1057/palgrave.ap.5500002.

Petrocik JR (1996) Issue Ownership in Presidential Elections, With a 1980 Case Study. American Journal of Political Science 40, 825-850.

Protsyk O and Garaz S (2013) Politicization of Ethnicity in Party Manifestos. Party Politics 19(2), 296-318. https://doi.org/10.1177/1354068811398058.

Saijo H (2020) The Effects of Electoral Anticipation on Portfolio Allocation. Party Politics, published early online, April. https://doi.org/10.1177/1354068820914547.

Sartori G (1976) Parties and Party Systems: Volume 1: A Framework for Analysis. Cambridge: Cambridge University Press.

Schumacher G and van Kersbergen K (2016) Do Mainstream Parties Adapt to the Welfare Chauvinism of Populist Parties? Party Politics 22(3), 300-312. https://doi.org/10.1177/1354068814549345.

Silva BC (2018) Populist Radical Right Parties and Mass Polarization in the Netherlands. European Political Science Review 10(2), 219-244. https://doi.org/10.1017/S1755773917000066.

Spoon J-J and Klïver H (2017) Does Anybody Notice? How Policy Positions of Coalition Parties are Perceived by Voters. European Journal of Political Research 56(1), 115-132. https://doi.org/10.1111/ 1475-6765.12169.

van der Brug W, Fennema $\mathbf{M}$ and Tillie J (2005) Why Some Anti-Immigrant parties Fail and Others Succeed: A Two-Step Model of Aggregate Electoral Support. Comparative Political Studies 38(5), 537573. https://doi.org/10.1177/0010414004273928. 
van Holsteyn JJ, Irwin GA and Den Ridder JM (2003) In The Eye of the Beholder: The Perception of the List Pim Fortuyn and the Parliamentary Elections of May 2002. Acta Politica 38(1), 69-87. https://doi. org/10.1057/palgrave.ap.5500004.

van Hoof AM, Kleinnijenhuis J, Oegema D and De Ridder J (2003) Guilt and Penance: Prospective and Retrospective Voting in 2002. Communications 28(4), 405-426. https://doi.org/10.1515/comm.2003.026. van Spanje J (2010) Contagious Parties: Anti-Immigration Parties and their Impact on Other Parties' Immigration Stances in Contemporary Western Europe. Party Politics 16(5), 563-586. https://doi.org/ $10.1177 / 1354068809346002$.

van Spanje J (2011) Keeping the Rascals In: Anti-Political-Establishment Parties and their Cost of Governing in Established Democracies. European Journal of Political Research 50(5), 609-635. https:// doi.org/10.1111/j.1475-6765.2010.01984.x.

van Spanje J and van der Brug W (2007) The Party as Pariah: The Exclusion of Anti-Immigration Parties and its Effect on their Ideological Positions. West European Politics 30(5), 1022-1040. https://doi.org/10. 1080/01402380701617431.

Wagner M and Meyer TM (2017) The Radical Right as Niche Parties? The Ideological Landscape of Party Systems in Western Europe, 1980-2014. Political Studies 65(1 suppl.), 84-107. https://doi.org/10.1177/ 0032321716639065.

Xu Y (2017) Generalized Synthetic Control Method: Causal Inference with Interactive Fixed Effects Models. Political Analysis 25(1), 57-76. https://doi.org/10.1017/pan.2016.2.

Cite this article: Hjermitslev IB (2022). Mainstream Sell-Outs? How Collaboration with the Radical Right Changes Perceptions of Party Positions on Immigration. Government and Opposition: An International Journal of Comparative Politics 57, 31-55. https://doi.org/10.1017/gov.2020.28 